Provided for non-commercial research and education use. Not for reproduction, distribution or commercial use.

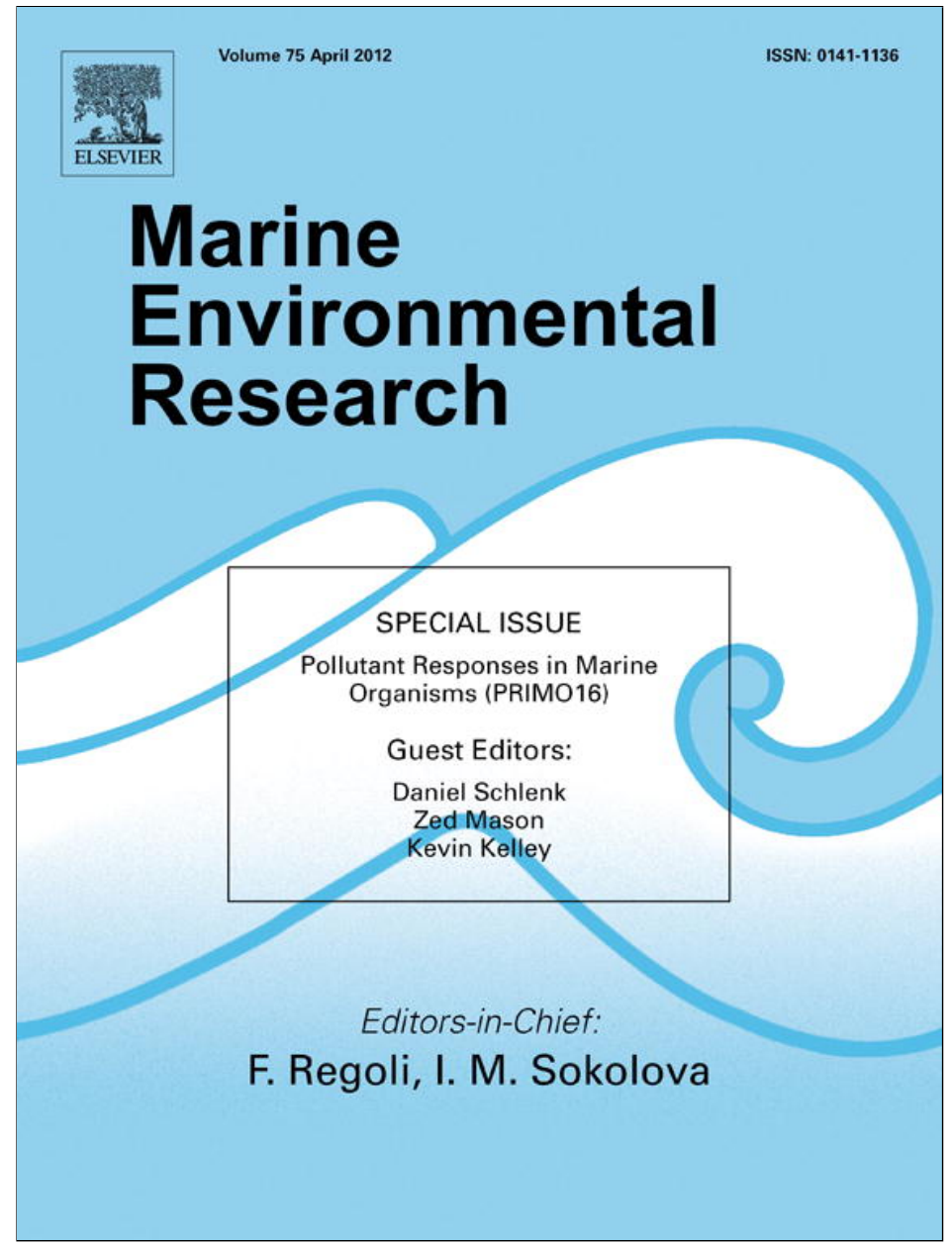

This article appeared in a journal published by Elsevier. The attached copy is furnished to the author for internal non-commercial research and education use, including for instruction at the authors institution and sharing with colleagues.

Other uses, including reproduction and distribution, or selling or licensing copies, or posting to personal, institutional or third party websites are prohibited.

In most cases authors are permitted to post their version of the article (e.g. in Word or Tex form) to their personal website or institutional repository. Authors requiring further information regarding Elsevier's archiving and manuscript policies are encouraged to visit:

http://www.elsevier.com/copyright 


\title{
Effects of various pollutant mixtures on immune responses of the blue mussel (Mytilus edulis) collected at a salinity gradient in Danish coastal waters
}

\author{
N. Höher ${ }^{a}{ }^{*}$, A. Köhler ${ }^{a}$, J. Strand ${ }^{b}$, K. Broeg ${ }^{a}$ \\ ${ }^{a}$ Alfred Wegener Institute for Polar and Marine Research, Am Handelshafen 12, 27570 Bremerhaven, Germany \\ ${ }^{\mathrm{b}}$ Aarhus University, Department of Bioscience, Frederiksborgvej 399, PO box 358, 4000 Roskilde, Denmark
}

\section{Keywords:}

Biomarker

Immune responses

Haemocytes

Mytilus spp.

Salinity

Baltic Sea

Redundancy analysis

\begin{abstract}
A B S T R A C T
The Baltic Sea is a semi-enclosed sea with a steady salinity gradient $(3 \%-30 \%)$. Organisms have adapted to such low salinities, but are suspected to be more susceptible to stress. Within the frame of the integrated environmental monitoring BONUS + project "BEAST" the applicability of immune responses of the blue mussel was investigated in Danish coastal waters. The sampling sites were characterised by a salinity range $(11-19 \%$ ) and different mixtures of contaminants (metals, PAHs and POPs), according to chemical analysis of mussel tissues. Variation partitioning (redundancy analysis) was applied to decompose salinity and contamination effects. The results indicated that cellular immune responses (total and differential haemocyte count, phagocytic activity and apoptosis) were mainly influenced by contaminants, whereas humoral factors (haemolytic activity) were mainly impacted by salinity. Hence, cellular immune functions may be suitable as biomarkers in monitoring programmes for the Baltic Sea and other geographic regions with salinity variances of the studied range.
\end{abstract}

Crown Copyright $\odot 2011$ Published by Elsevier Ltd. All rights reserved.

\section{Introduction}

Environmental pollution of coastal and estuarine areas has an impact on immune responses of aquatic organisms (Canesi et al., 2007; Dyrynda et al., 1998; Galloway and Depledge, 2001; Hannam et al., 2009; Pipe and Coles, 1995; Pipe et al., 1999), which is suspected to be associated with an increase of disease susceptibility. Thus, biomarkers that specifically elucidate immunotoxic effects may act as useful tools in integrated chemical and biological effect monitoring programmes. Further, potential ecologically relevant impacts on the health of marine organisms may be predicted at an early stage. Additionally, there is evidence that immunological functions are extremely sensitive to anthropogenic chemicals at exposure concentrations that are not toxic (Duchemin et al., 2008; Galloway and Depledge, 2001; Liu et al., 2009).

Therefore, immunotoxic effects have been identified as a potential novel tool in the BONUS + funded project BEAST (Biological effects of anthropogenic chemical stress in the Baltic Sea). The overall project is aimed towards the testing and implementation of indicators for biological effects of contaminants

\footnotetext{
* Corresponding author. Tel.: +49 4714831 1618; fax: +49 47148311425 .

E-mail addresses: nicole.hoeher@awi.de (N. Höher), angela.koehler@awi.de (A. Köhler), jak@dmu.dk (J. Strand), katja.broeg@awi.de (K. Broeg).
}

(biomarkers) in the Baltic Sea, one of the largest brackish water areas in the world, and their integrated assessment. Specific characteristics of the Baltic Sea like the predominant salinity gradient (3-30\%) pose a great challenge for the application of biomarkers, since it has to be taken into consideration that salinity might act as a significant confounding factor. Another challenge is the choice of eligible indicator species. One prerequisite is the availability of the species in almost all different sub regions with variable salinity of the Baltic Sea.

Bivalve molluscs, mainly Mytilus spp, have been implemented as bioindicator species in a number of environmental monitoring programmes based on their sedentary and ubiquitous inhabitancy of coastal and estuarine areas in the Northern hemisphere, including the Baltic Sea. Blue mussels are permanently exposed to contaminants in the water column due to their filter-feeding behaviour and accumulate toxins (Dagnino et al., 2007; Widdows and Donkin, 1992).

Predominately, Mytilus spp. are used widely to assess the effects of specific pollutants on physiological responses as mortality, shell valve gap, scope for growth, shell and tissue growth (Widdows and Donkin, 1992), but also on sub-cellular and molecular responses like lysosomal membrane stability, acetylcholinesterase (AChE) activities, micronuclei and DNA strand breaks (Broeg and Lehtonen, 2006; Oehlmann and Schulte-Oehlmann, 2003; Rank et al., 2007; Schiedek et al., 2006). 
The majority of the abovementioned studies focused on marine environment (30-37\%) and did not include brackish habitats, which Mytilus spp. are able to inhabit due to their euryhaline characteristics. However, due to their poikilosmotic character, mussels cannot maintain an inner osmotic concentration that differs from the external medium (Tedegren and Kautsky, 1986). The reduction of intracellular ions at low salinities is energetically unfavourable and leads to lower growth rate and smaller size, as seen in Baltic Sea mussels compared to North Sea mussels (Prevodnik et al., 2007; Tedegren and Kautsky, 1986). Hence, we hypothesize that those energy restrictions will have a limiting effect on homeostasis and immune responses since the production of reactive oxygen species to fight bacteria might be impaired.

Homeostasis including the normal functioning of haemocytes is essential for the well being of an organism, which may be accomplished by apoptosis (Kiss, 2010; Krysko et al., 2008). The programmed death of damaged cells plays a key role in the immune system, since it prevents inflammatory damage of surrounding tissues and protects the host from pathogen spreading (Krysko et al., 2008). Pirger et al. (2009) showed that classical mitochondrial outer membrane permeability (MOMP), cytochrome c, apoptosome and caspase-dependent pathways are present in molluscs. The activity of effector caspases at the end of the caspase cascade, like caspase 3, may give an indication for apoptotic processes. Kiss (2010) suggested, that apoptosis might be a useful biomarker, since it provides mechanistic information on the impact of environmental and xenobiotic pollutants. Further, normal homoeostasis of haemocytes can be determined by histopathological techniques, as employed in other molluscan tissues (Auffret, 1988; Thompson et al., 1978).

The main function of the immune response of all organisms is to provide protection against infectious agents as there are bacteria, viruses, fungi, parasites, and cancer cells, as well as to reject nonself components (Galloway and Depledge, 2001; Galloway and Goven, 2006). Invertebrates rely on innate immune defences, which are accomplished by haemocytes and soluble haemolymph factors (Canesi et al., 2006). The haemolymph acts as a carrier of haemocytes, humoral defence factors like soluble lectins, hydrolytic enzymes, antimicrobial peptides, and cellular mediators, such as prophenoloxidase, lectins, cytokines and eicosanoids (Canesi et al.,
2006, 2002; Galloway and Depledge, 2001). Phagocytosis is the predominant mechanism of cellular defence, which, in bivalves, is mainly mediated by circulating and tissue haemocytes (Pipe and Coles, 1995; Pipe et al., 1999). This process proceeds through a number of well-defined stages: recognition, chemotaxis, attachment, respiratory burst, ingestion, and destruction (Galloway and Goven, 2006); and has been focused on as biomarkers for immunotoxic effects in a number of studies (Bussell et al., 2008; Canesi et al., 2007; Pipe et al., 1999; Reid et al., 2003). Here, phagocytic activity (uptake of neutral red stained zymosan particles) and apoptosis of haemocytes (caspase 3/7 activity) were analysed as cellular and haemolytic activity (lysis of erythrocytes) as humoral endpoints. In addition, total cell counts (count of formaldehydefixed cells in Neubauer chamber) and differential cell counts as well as abnormalities in morphological features of haemocytes were determined microscopically (May-Grünwald/Giemsa stained haemocyte smears). To test the impact of both, salinity and contamination, different sites with salinity range between 11 and $19 \%$ and various contaminant mixtures were examined. In parallel, mussel were analysed for their contaminant burden. The respective impacts of the different factors on the studied immune parameters were evaluated by the use of multivariate statistics.

\section{Methods}

\subsection{Sampling}

Sampling was conducted in November 2009 in Danish coastal waters surrounding the island Zealand (Fig. 1). Sampling sites are characterised by differing salinities (salinity at sampling day), including Agersø $(11 \%)$, Roskilde Fjord and Roskilde Vig (both $13 \%$ ), Frederiksværk (15\%) and Isefjord (19\%). See Table 1 for yearly means, determined by Conley et al. (2000). Temperatures ranged between 8 and $9{ }^{\circ} \mathrm{C}$. Mussels were collected from 1 to $3 \mathrm{~m}$ depth, kept in sufficient volumes of aerated water from the respective collection site and analysed within $24 \mathrm{~h}$. Measurements of mussels were not significantly different between sites (length: $5.06 \pm 0.48 \mathrm{~cm}$; width: $1.98 \pm 0.29 \mathrm{~cm}$; height: $2.27 \pm 0.29 \mathrm{~cm}$; mean $\pm \mathrm{SD} ; N=121)$. Gametogenesis of gonads generally rests in October and November (Kautsky, 1982; Seed, 1975, 1976); therefore
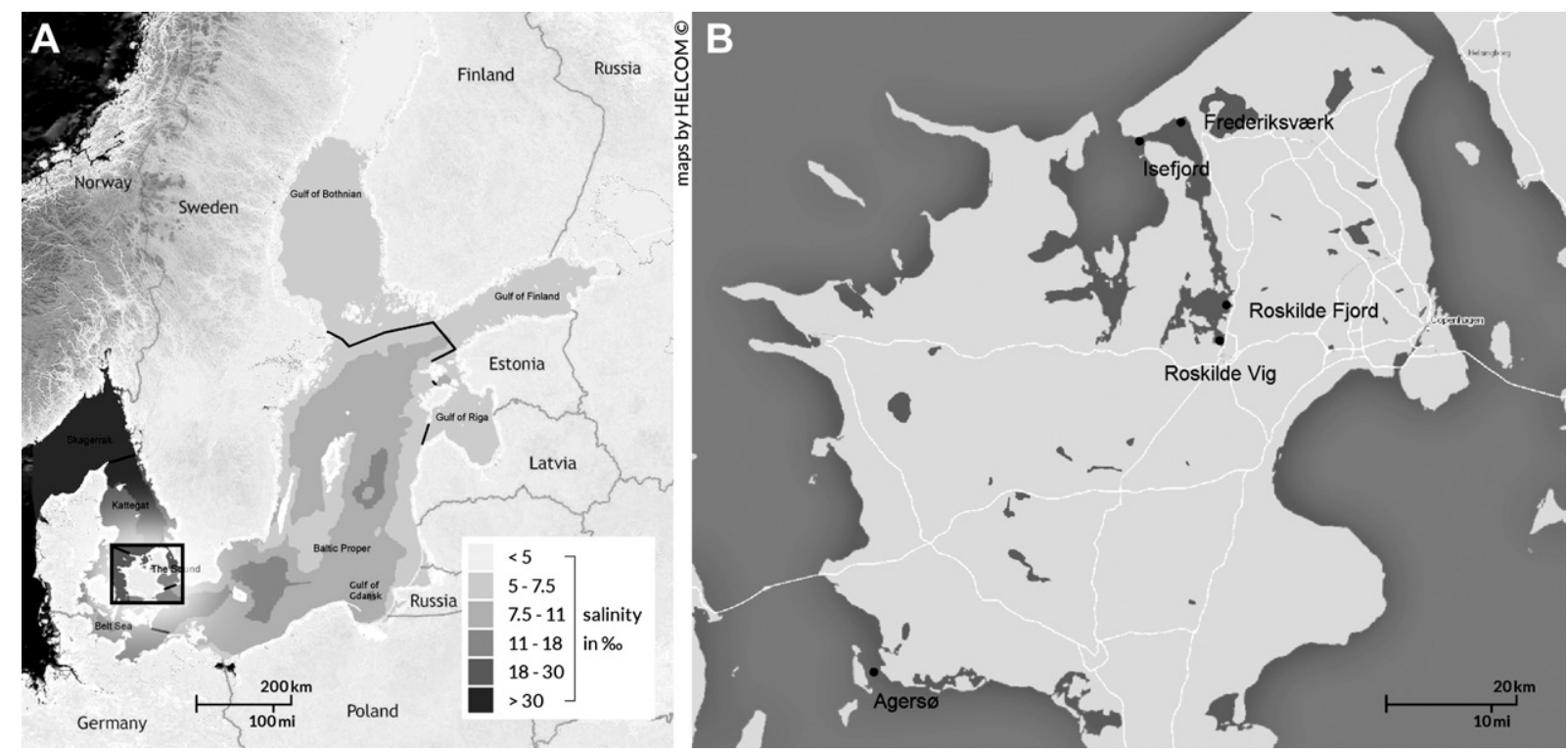

Fig. 1. (A) Map of Baltic Sea indicating salinity range; (B) sampling sites in Danish coastal waters, Zealand. 
Table 1

Sampling sites, potential sources of contamination and salinity at time of the sampling, average salinity (mean \pm SD) as determined by Conley et al. (2000) between 1989 and 1995.

\begin{tabular}{|c|c|c|c|}
\hline Station & Sources of contamination & $\begin{array}{l}\text { Salinity } \\
{[\%]}\end{array}$ & $\begin{array}{l}\text { Mean } \\
\text { salinity } \pm \mathrm{SD} \\
{[\%]}\end{array}$ \\
\hline Agers $\emptyset$ & $\begin{array}{l}\text { International shipping lane, } \\
\text { some industry and agriculture. }\end{array}$ & 11 & $13 \pm 2.5$ \\
\hline Roskilde Vig & Larger marina and a larger city. & 13 & $15 \pm 3$ \\
\hline Roskilde Fjord & $\begin{array}{l}\text { Larger city and freshwater } \\
\text { runoff from agriculture. }\end{array}$ & 13 & $15 \pm 3$ \\
\hline Frederiksværk & $\begin{array}{l}\text { Larger city, iron-melt industry, } \\
\text { and some freshwater runoff } \\
\text { from agriculture. }\end{array}$ & 15 & $18 \pm 2$ \\
\hline Isefjord & $\begin{array}{l}\text { Mainly freshwater runoff from } \\
\text { agriculture. }\end{array}$ & 19 & $18 \pm 2.5$ \\
\hline
\end{tabular}

it is assumed that the collected mussels were in the resting developmental stage.

Sites sampled during the present study have been monitored by the Nationwide Monitoring and Assessment Programme for the Aquatic and Terrestrial Environment (NOVANA) in Denmark on a regular basis since 1998. Therefore long term data sets in terms of contaminants are available.

\subsection{Condition index}

Mussel condition indices $(\mathrm{CI})$ related shell to living tissue quantity and were calculated as described by Davenport and Chen (1987).

$\mathrm{CI}=\frac{\text { tissue wet weight }}{\text { shell weight }} \times 100$

\subsection{Haemolymph withdrawal}

The valves were slightly opened with scissors and held open with a pipette tip, excess water was drained and haemolymph withdrawn from the adductor muscle. To prevent both, aggregation and any negative osmotic effects, the syringe contained a HEPESbuffered physiological saline ( $\mathrm{pH} 7.2,426 \mathrm{mM} \mathrm{NaCl}, 53 \mathrm{mM}$ MgSO4, $10 \mathrm{mM} \mathrm{KCl}, 13.2 \mathrm{mM} \mathrm{CaCl} 2,20 \mathrm{mM}$ HEPES) (Moore and Lowe, 2004). HEPES (20 mM, pH 7.2) was also used as dilution medium to adjust salinity, thus osmolality, with regard to the salinity measured at the sampling stations.

\subsection{Total/differential haemocyte count}

An aliquot $(50 \mu \mathrm{l})$ of the haemolymph was fixed with an equal amount of Baker's formaldehyde (4\%). Cells were counted with an improved Neubauer chamber to determine a measure for the total number of circulating haemocytes.

Aliquots of unfixed haemolymph $(30 \mu \mathrm{l})$ was smeared onto polyL-lysine coated microscope slides, allowed to adhere in a moist chamber for $30 \mathrm{~min}$, dried, and fixed with methanol (100\%, $5 \mathrm{~min}$ ). Cells were stained with May-Grünwald ( $5 \mathrm{~min}$ ), washed in aqua dest $\left(1 \frac{1}{2} \mathrm{~min}\right)$, stained with $5 \%$ Giemsa ( $\left.13 \mathrm{~min}\right)$, followed by a short washing step (1 $1 / 2 \mathrm{~min}$ in aqua bidest.) according to Aladaileh et al. (2007) and optimized Sigma ${ }^{\circledR}$ staining protocols. Slides were allowed to dry and subsequently mounted with Euparal. Three major haemocyte types (granulocytes, hyalinocytes and small basophilic haemocytes) were identified by light microscopy based on nucleus:cytoplasm ration and the presence or absence of cytoplasmic granules (Aladaileh et al., 2007). At least 200 cells were counted under a light microscope $(1000 \times)$ to determine the ratio of the three haemocyte types. Additionally, the occurrence of vacuolation as well as nuclear abnormalities, like multinucleated haemocytes (primarily micronuclei and binucleated cells) and deformation of the nucleus such as blebbing as described by Fenech et al. (2003) was noted.

\subsection{Phagocytosis}

Aliquots of haemolymph $(50 \mu \mathrm{l})$ were added to a 96-well cellculture plate and haemocytes were allowed to adhere $(1 \mathrm{~h}$ at $\left.5^{\circ} \mathrm{C}\right)$. Neutral red stained zymosan particles $\left(1 \times 10^{6}\right)$ were added in equal volumes to each sample $(30 \mathrm{~min})$. Cells were fixed, washed and solubilized with acidified ethanol (1:50). The absorbance was determined spectrophotometrically (550 nm; via a microplate reader). Phagocytic index was expressed as absorbance of NRstained particles $\times 10^{6}$ per number of granulocytes. To adjust the determined phagocytic activity the uptake of Neutral Red stained zymosan particles was analysed with regard to the granulocyte count as opposed to the measured protein content (Pipe et al., 1999), based on studies showing that granulocytes are the major immune effector cells particularly concerning phagocytosis (reviewed by Hine, 1999).

\subsection{Caspase activity}

Caspase 3 and 7 activity was assessed as an endpoint for apoptosis. Both caspases, 3 and 7, are effector proteins at the end of a cascade, which is irreversible once the pro-caspases have been cleaved resulting in the generation of active caspases, inducing programmed cell death in the concerning cells.

The Caspase-Glo ${ }^{\circledR} 3 / 7$ Assay (Promega, U.S.A.) is a homogeneous, luminescence assay, which can be employed to measure Caspase 3 and Caspase 7 activity. The Caspase-Glo ${ }^{\circledR} 3 / 7$ reagent contains the tetrapeptide sequence DEVD (also luciferase and cell lytic substances); its reaction with caspase 3 and 7 leads to a caspase cleavage and a substrate for luciferase (amino-luciferin) is released, which results in the luciferase reaction and the production of light. Caspase 3/7 activity was expressed as luminescent units (LU) per mg protein.

\subsection{Haemolytic activity}

The haemolytic potential was investigated as humoral immune response by the capacity of haemocytes by lysing sheep erythrocytes extracellularly (Hannam et al., 2009; Malagoli et al., 2007). Haemolymph was centrifuged ( $300 \mathrm{~g}, 15 \mathrm{~min}$ ) and the supernatant was stored at $-80{ }^{\circ} \mathrm{C}$ prior to analysis. Equal amounts $(100 \mu \mathrm{l})$ of cell-free haemolymph and erythrocytes $\left(1 \times 10^{7}\right.$ cells $\left./ \mathrm{ml}\right)$ were incubated in a microtitre plate (V-wells) at $25^{\circ} \mathrm{C}(1 \mathrm{~h})$ and subsequently centrifuged. The supernatant was transferred into a flat bottom 96-well plate and analysed photometrically at $415 \mathrm{~nm}$. Haemolytic activity was expressed as percentage with regard to the maximum absorbance provided by a positive control $\left(\mathrm{ddH}_{2} \mathrm{O}\right)$.

\subsection{Chemistry}

The contaminant data for PCBs, organochlorine pesticides, PAHs, organotins, and metals have been provided due to cooperation with the marine part of the Nationwide Monitoring and Assessment Programme for the Aquatic Environment and Nature (NOVANA) in Denmark (Dahllöf and Andersen, 2009).

The chemical analyses were performed on a pool of mussels (about 50, corresponding to $100 \mathrm{~g}$ fresh weight, Tables 2 and 3) 
Table 3

Significant Pearson correlations $(R>0.7)$ between contaminants and salinity. The first stated explanatory variables were used in (partial) redundancy analysis based on collinearity and the variance inflation factor (VIF $<3$ ).

\begin{tabular}{|c|c|c|}
\hline & \multicolumn{2}{|l|}{ Pearson Correlation $(R>0.7)$} \\
\hline & Positive & Negative \\
\hline Salinity & Trans-nonachlor & $\mathrm{Pb}, \mathrm{PAH}$ \\
\hline TBT & DBT, MBT, DDT, Zn, Cr & \\
\hline $\mathrm{Cu}$ & As, Trans-nonachlor & $\mathrm{Zn}, \mathrm{PCB}$ \\
\hline $\mathrm{HCH}$ & $\mathrm{Ni}$ & PCB \\
\hline $\mathrm{Zn}$ & TBT, DBT, MBT, DDT, Cr, PCB & $\begin{array}{l}\mathrm{Cu}, \mathrm{As}, \mathrm{HCH} \text {, } \\
\text { Trans-nonachlor }\end{array}$ \\
\hline $\mathrm{Hg}$ & DBT, MBT, DDT, Cd, Cr, PAH, HCB & \\
\hline $\mathrm{Cd}$ & $\mathrm{Hg}, \mathrm{PAH}, \mathrm{HCH}, \mathrm{HCB}$ & \\
\hline $\mathrm{Pb}$ & $\mathrm{PAH}$ & $\begin{array}{l}\text { Salinity, } \\
\text { Trans-nonachlor }\end{array}$ \\
\hline $\mathrm{Cr}$ & TBT, DBT, MBT, DDT, Zn, Hg, PAH, & \\
\hline As & $\mathrm{Cu}$, Trans-nonachlor & Zn, PCB \\
\hline $\mathrm{PAH}$ & $\mathrm{Hg}, \mathrm{Cd}, \mathrm{Pb}, \mathrm{Cr}, \mathrm{DDT}$ & Salinity \\
\hline PCB & Zn, & $\begin{array}{l}\mathrm{Cu}, \mathrm{As}, \mathrm{HCH}, \mathrm{HCB} \text {, } \\
\text { Trans-nonachlor }\end{array}$ \\
\hline DDT & TBT, DBT, MBT, Hg, Pb, Cr, PAH & \\
\hline $\mathrm{HCB}$ & $\mathrm{Cu}, \mathrm{Hg}, \mathrm{Cd}$ & PCB \\
\hline Trans-nonachlor & Salinity, As & $\mathrm{Pb}, \mathrm{PCB}$ \\
\hline
\end{tabular}

collected at the same time and site as for the biological effect measurements. Mussels for chemical analyses were treated according to the NOVANA monitoring guideline (Larsen et al., 2011a). In brief, they were depurated in 12-24 h, followed by dissection, biometric measurements and Ultra Turrax homogenisation of the pool of whole soft bodies before the homogenate was divided into several subsamples, which were stored frozen at $-20^{\circ} \mathrm{C}$ until analyses. Only the subsample for metal analyses was freeze dried before analyses, whereas the analyses of the organic compounds were performed on wet materials. The determination of the lipid content was performed according to Smedes (1999).

Organochlorine compounds including polychlorinated biphenyls (PCBs: CB-28 3144, 49, 52, 99, 101, 105,110, 118, 128, 138, 149, 151,153, 156, 170, 180 and 187), and the pesticides dichlorodiphenyltrichloroethanes (DDTs: o'p-DDE, o'p-DDT, p'p'-DDD, p'p-DDE, p'pDDT), hexachlorocyclohexanes (HCHs: alpha- $\mathrm{HCH}$, beta- $\mathrm{HCH}$, gamma-HCH), Hexachlorobenzene ( $\mathrm{HCB}$ ), and trans-nonachlor (a derivate of chlordane) and polycyclic aromatic hydrocarbons (PAHs: naphthalene, 2-methylnaphthalene, 1-methylnaphthalene, dimethylnaphthalene, trimethylnaphthalene, acenaphthylene, acenaphthene, fluorene, dibenzothiophene, methyldibenzothiophene, Phenanthrene, methylphenanthrene, dimethylphenanhtrene, anthracene, benz(a)fluorene, fluoranthene, pyrene, 1-methylpyrene, benz(a)anthracene, chrysene/triphenylene, benz $(b+j+k)$ fluoranthene, benz(e)pyrene, benz(a)pyrene, perylene, indeno(1.2.3-cd) pyrene, benz(ghi)perylene, dibenz(a.h)anthracene) were analysed with GC-ECD and GC-MS, respectively, according to the method described in Vorkamp et al. (2010). Organotin compounds (TBT, DBT, MBT, TPhT) were analysed with GC-PFPD according to Strand et al. (2003), and the trace metals $\mathrm{Zn}, \mathrm{Cu}, \mathrm{Cd}, \mathrm{Hg}, \mathrm{Pb}, \mathrm{Ni}, \mathrm{Cr}$, As, were analysed with ICP-MS or AA according to Larsen et al. (2011b).

Laboratory procedures and quality assurance followed accredited methods and include satisfactory recoveries on certified reference materials and participation in international intercalibrations e.g. organised by Quasimeme (www.quasimeme.org). Detection limits and quality assurance follow the recommendations of the JAMP Guidelines for Monitoring Contaminants in Biota (OSPAR, 1999).

\subsection{Statistical analysis}

All biological data were expressed as median \pm SD, N (7-11) were stated for each parameter accordingly. Kruskal-Wallis Tests 
were performed using STATISTICA ${ }^{\odot} 9.1$ (StatSoft Inc.) to analyse differences in the biological parameters between stations. Significant differences between stations are highlighted with rejection of the null hypothesis at the 5\% probability level $(P<0.05)$.

Variation partitioning, particularly redundancy analysis (RDA), was applied to explain the variation of the biological responses by the two groups of explanatory variables: salinity and contaminants (Legendre, 2008). Thus, the variance (sum of canonical eigenvalues, $\lambda$ ) within the variables are separated into several components, each reflecting the relative importance of either salinity or contaminants, as well as their shared effects (Borcard et al., 1992; Zuur et al., 2007). Variation was partitioned using a series of (partial) RDAs as implemented in the program BRODGAR ${ }^{\odot}$ (Highstat Statistics Ltd) and described by Zuur et al. (2007).

In brief, as summarized in Table 4, RDA was performed for both groups of explanatory variables (step 1 ), followed by RDAs for each explanatory variable group, salinity (step 2) and contaminants (step 3), respectively. Two partial RDAs were conducted with both groups of explanatory variables and additional co-variables; salinity (step 5) and contaminants (step 4), respectively. All (partial) RDAs were performed with a forward selection procedure and the associated permutation test (9999 random permutations). Further, the above-determined variances were decomposed by assessing 4 components (A, B, C and D, Table 5). Components A and $B$ are equal to the explained variances in step 5 and 4, respectively. $C$ is equal to variance in step 3 minus variance in step 5 , and $D$ is calculated as total variance (in RDA: 1) minus the explained variance in step 1.

Rules for the interpretation of the RDA correlation triplot were summarized by Zuur et al. (2007), in brief, angles between lines represent correlation $\left(90^{\circ}\right.$ : no correlation; 0 and $180^{\circ}$, positive and negative correlation, respectively), length of the lines is proportional to the variance of the particular variable and points for observations, which cannot be compared directly with each other, can be projected perpendicular on the lines and indicate values for the explanatory variable.

Collinearity was assessed within the group of contaminants conducting Pearson correlation and analysis of variance inflation factors (VIF < 3); thus copper, $\sum \mathrm{HCH}$ and TBT were considered for variation partitioning. Further, square root transformation was performed on phagocytic activity, condition index, caspase 3/7 activity data and number of haemocytes with vacuolation, due to outliers.

\section{Results}

\subsection{Condition index}

Lowest condition indices were found at Isefjord ( $29.3 \pm 10.8$; $N=10$ ), whereas highest indices were calculated for mussels from Roskilde Vig $(69.3 \pm 27.5 ; N=10)$ and Agersø $(51.6 \pm 12.3 ; N=10)$,

Table 4

Results of (partial) RDA analyses, indicating sum of canonical eigenvalues ( $\lambda$ ), Fstatistics and $P$-values.

\begin{tabular}{|c|c|c|c|c|c|c|}
\hline Step & Analysis & $\begin{array}{l}\text { Explanatory } \\
\text { variable }\end{array}$ & Covariable & $\lambda$ & F-statistics & $P$-value \\
\hline 1 & RDA & $\begin{array}{l}\text { Salinity and } \\
\text { contaminants }\end{array}$ & & 0.25 & 4.112 & $<0.001$ \\
\hline 2 & RDA & Salinity & & 0.06 & 3.336 & $<0.01$ \\
\hline 3 & $\mathrm{RDA}$ & Contaminants & & 0.17 & 2.419 & 0.013 \\
\hline 4 & Partial RDA & Salinity & Contaminants & 0.08 & 5.234 & $<0.001$ \\
\hline 5 & Partial RDA & Contaminants & Salinity & 0.19 & 4.112 & $<0.001$ \\
\hline
\end{tabular}

Table 5

Variance decomposition table showing the effects of salinity and contaminants. Components A, B, C and D as described previously.

\begin{tabular}{llllr}
\hline Component & Source & Calculation & $\lambda$ & $\%$ \\
\hline A & Pure contaminants & & 0.19 & 19 \\
B & Pure salinity & & 0.08 & 8 \\
C & Shared & $0.17-0.19^{\mathrm{a}}$ & 0.00 & 0 \\
D & Residuals & $1.00-0.25$ & 0.75 & 75 \\
Total & & & & 102
\end{tabular}

a Components can take negative values as they are based on coefficients of determination. They are interpreted as zeros since they correspond to cases where explanatory cases explain less variation than random normal variables would (Legendre, 2008). The percentage may not add up to 100, due to rounding errors (Zuur et al., 2007).

both were significantly different from Isefjord $(P<0.001$; Kruskal-Wallis, Fig. 2).

\subsection{Total/differential cell count}

The average total number of circulating haemocytes ranged from $0.38 \times 10^{6}$ to $1.4 \times 10^{6}$ cells per ml (Fig. 3 ). Lowest numbers were detected in mussels from Roskilde Ford and Isefjord $\left(29.2 \pm 31.1 \times 10^{4}\right.$ and $20.7 \pm 36.0 \times 10^{4}$ cells $\mathrm{ml}^{-1}$, respectively; $N=10$ ), which were significantly different to counts determined in

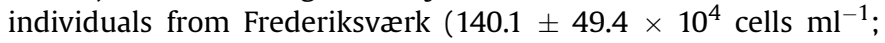
$N=10 ; P<0.01 ;$ Kruskal-Wallis).

Granulocytes comprised 54-64\%, hyalinocytes $28-40 \%$ and small basophilic cells $2-14 \%$ of the total haemocyte population. Although, the mere count (ratio) of the cell types did not show any differences among sites, changes of the morphology were determined. Morphological features of studied abnormalities are shown in Fig. 4.

The most notable events were vacuolation, occurrence of multinucleated haemocytes (including Micronuclei and mostly binucleated cells) as well as nuclear deformation.

Individuals from Frederiksværk showed significantly higher occurrences of vacuolation $\left(4.9 \pm 6.5 \times 10^{4}\right.$ cells $\mathrm{ml}^{-1} ; N=9$; $P<0.001$, Kruskal-Wallis) compared with mussels from Roskilde Vig $\left(0.04 \pm 0.7 \times 10^{4}\right.$ cells $\left.\mathrm{ml}^{-1} ; N=8\right)$ and Roskilde Fjord $\left(0.58 \pm 0.7 \times 10^{4}\right.$ cells $\mathrm{ml}^{-1} ; N=7$; Fig. 5$)$. Deformations of the nucleus were determined at Frederiksværk and Agersø as well as an increased occurrence of polynucleated haemocytes at

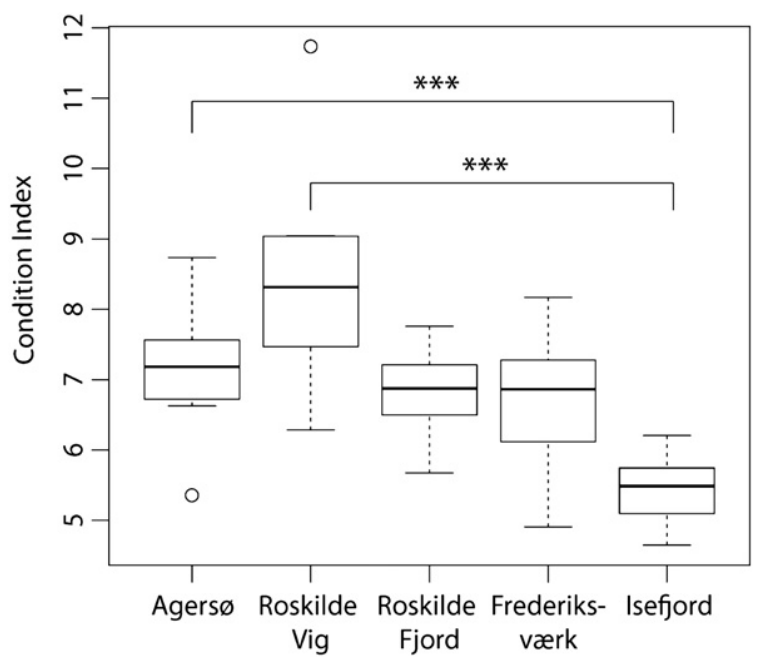

Fig. 2. Condition indices (ratio between shell and tissue weight), *** indicate significant differences among sampling sites $(P<0.001)$ 


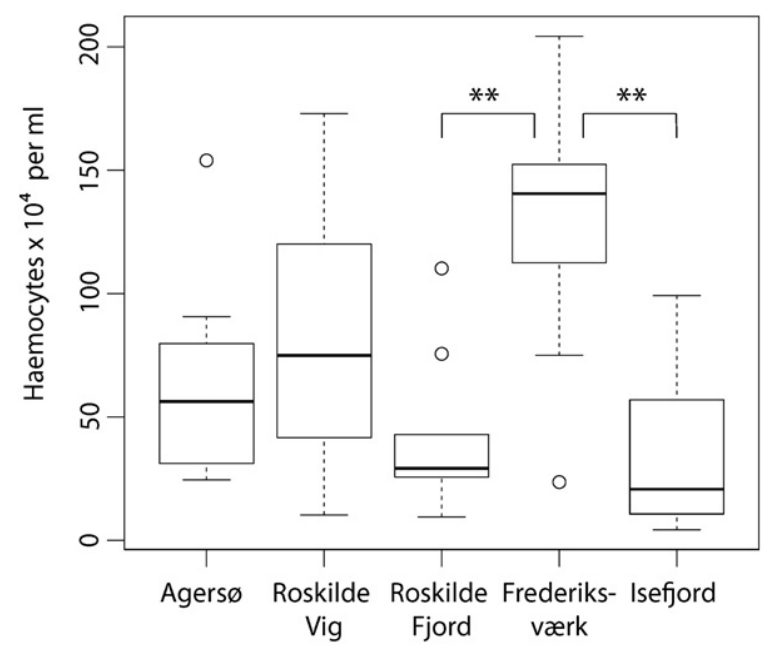

Fig. 3. Total Haemocyte Count (haemocytes $\times 10^{4}$ per ml) determined by implementation of an Improved Neubauer Chamber $(400 \times)$, ** indicate significant differences among sampling sites $(P<0.01)$.

Frederiksværk, however both observations were not significantly different to the other stations.

\subsection{Phagocytic activity}

Mussels from Roskilde Fjord $(8.0 \pm 8.1$ NR-stained zymosan particles/granulocyte; $N=8$ ) showed significantly elevated phagocytic activity compared to individuals from Frederiksværk
$(1 \pm 1.3$ NR-stained zymosan particles/granulocyte; $N=8 ; P<0.05$; Kruskal-Wallis, Fig. 6). Phagocytic activity at other stations was generally as low as detected at Frederiksværk.

\subsection{Caspase activity}

Caspase activity did not show any differences among stations.

\subsection{Haemolytic activity}

Individuals from Roskilde Vig and Roskilde Fjord showed little haemolytic activity $(0.3 \pm 0.1, N=10 ; 0.1 \pm 0.1, N=11$, respectively), however higher haemolytic activity was determined in mussels from Agersø and Isefjord $(1.2 \pm 2.2, N=10 ; 12.5 \pm 25.5, N=9$, respectively; Fig. 7).

\subsection{Chemical analysis}

The sampling sites were characterized by a wide range of various chemicals (Table 2). Organisms from Frederiksværk (15\%), a station with an iron-melt industry, showed high body burdens of PCBs. At Roskilde Vig $(13 \%$ o), a large marina, mussels contained highest levels of most analysed chemicals, including PAHs and TBT. A station nearby and same salinity, Roskilde Fjord, was particularly polluted by $\mathrm{Zn}, \mathrm{Cu}$ and $\mathrm{Pb}$. The less contaminated sites were Agersø $(11 \%)$ and Isefjord $(19 \%)$, being characterized by the impact of an international shipping lane and agricultural runoff, respectively. Collinearity between chemicals, assessed by Pearson correlation $(R>0.7)$ was summarized in Table 3.

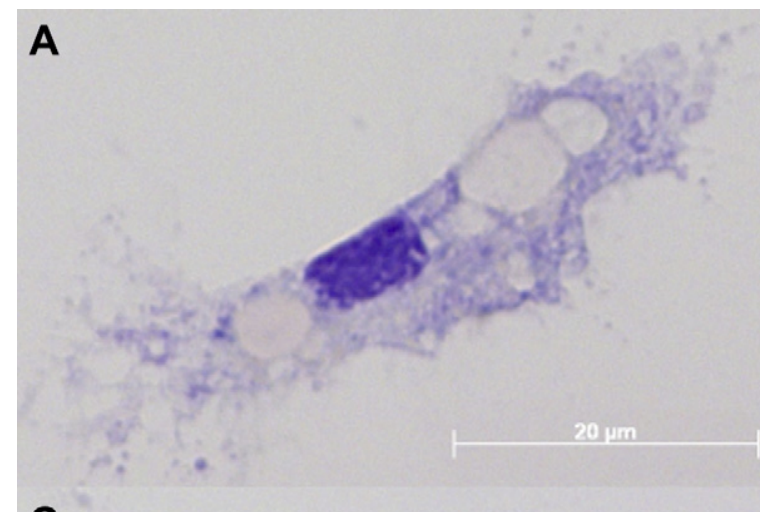

\section{B 1}

C
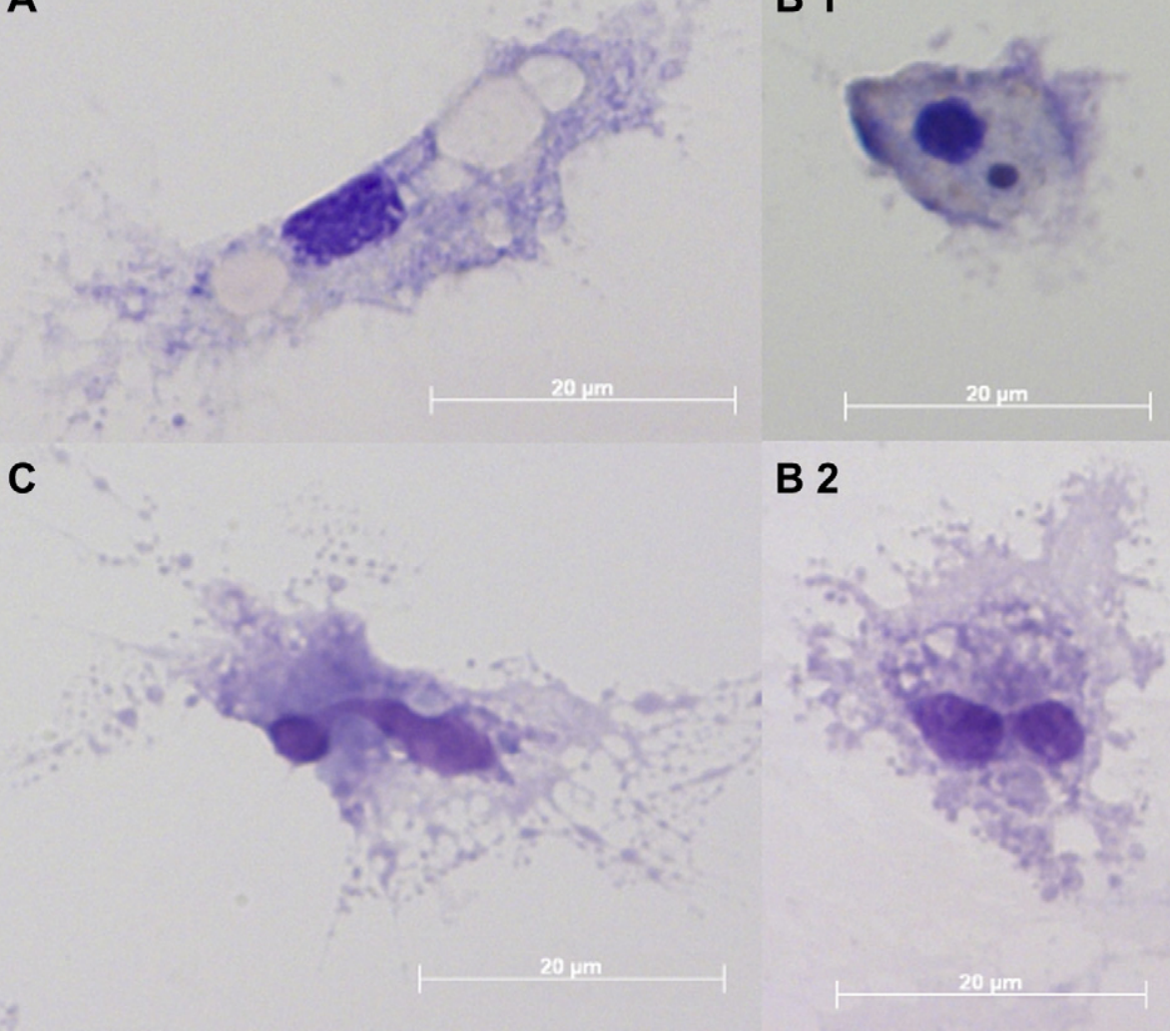

Fig. 4. Determined morphological abnormalities in haemocytes (May-Grünwald and Giemsa staining, light microscopy with oil, 1000× ). A: vacuolation. B: multinucleated haemocytes ((1) micronuclei, (2) binucleated cell). C: deformation of the nucleus. 


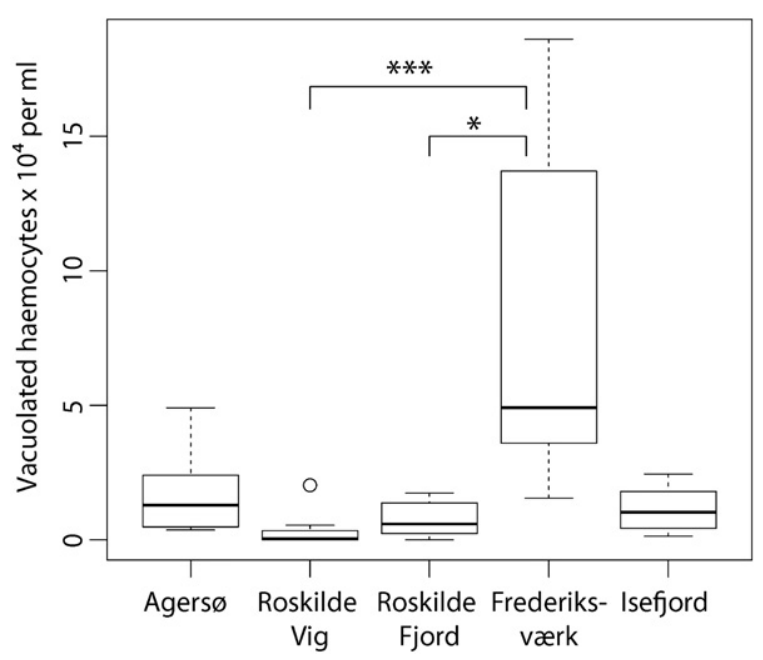

Fig. 5. Vacuolated haemocytes, percentaged occurrence was assessed in haemocyte smear (May-Grünwald and Giemsa staining, light microscopy with oil, 1000×) and normalized by THC, $* * *$ indicate significant differences among sampling sites $(P<0.001)$; * indicate significant differences among sampling sites $(P<0.05)$.

\subsection{Redundancy analysis}

The explanatory variables, salinity and contaminants $(\mathrm{Cu}, \mathrm{TBT}$, $\sum \mathrm{HCH}$ ), account for $25 \%$ of the variation in the data (sum of canonical eigenvalues, $\lambda$ ) as assessed with RDA (step 1, Table 4). From this $25 \%$, the first two axes explain $80.8 \%$ (eigenvalue as cumulative percentage of the sum of all eigenvalues), thus those axes explain $20.5 \%$ of the variation in the biological responses. The RDA analysis and the RDA correlation triplot (Fig. 8) indicated that axis 1 , representing $48.7 \%$ of all variations, could be accounted for the number of circulating haemocytes (THC), morphological abnormalities (deformations of nuclei, vacuolation and polynucleated haemocytes), phagocytic activity and copper. Axis 2 accounted for $32.1 \%$ of the variances, which are mainly explained by condition indices, salinity and haemolytic activity. The interpretation of the RDA correlation triplot (Fig. 8) indicated that haemolytic activity is correlated with salinity, driving the biological responses in mussels from Isefjord. In contrast, mussels from Roskilde Fjord

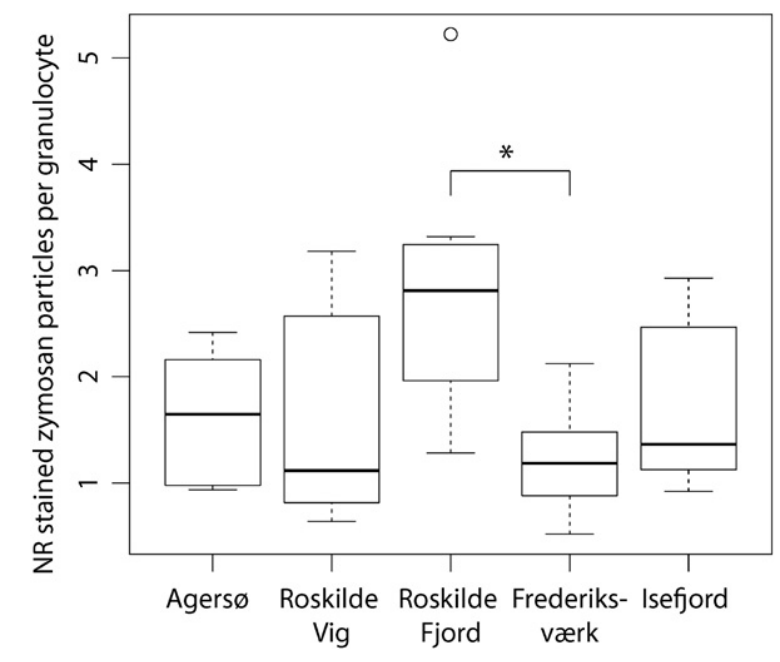

Fig. 6. Phagocytic activity, determined by the uptake of NR-stained zymosan particles and normalized by granulocyte count, * indicate significant differences among sampling sites $(P<0.05)$.

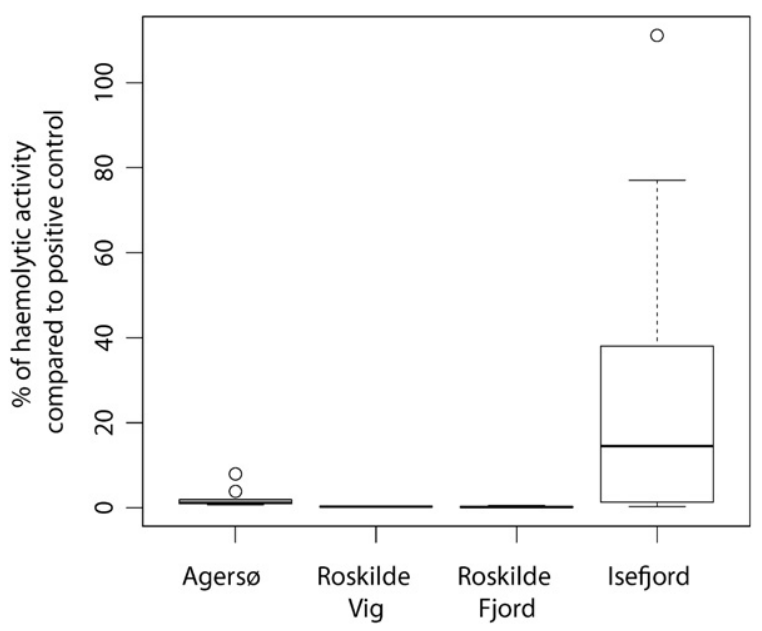

Fig. 7. Haemolytic activity, assessed as lysis of erythrocytes and normalized by the highest extinction of the positive control $\left(\mathrm{ddH}_{2} \mathrm{O}\right)$.

related positively with phagocytic activity and copper concentrations. Cellular deformation (vacuolation, nuclear deformations and multinucleated haemocytes) were related to organisms from Frederiksværk.

The RDA and partial RDA were statistical significant (Table 4). A summary of the variation partitioning suggested that the pure salinity effect accounted for $8 \%$ of the variation in biological responses (Component $A$, Table 5), whereas contaminants explained $19 \%$ of the determined variation (Component B, Table 5). The shared effect between salinity and contaminants accounted for none of the observed variation (Component C, Table 5). The marginal effects as assessed by forward selection (by adding each of

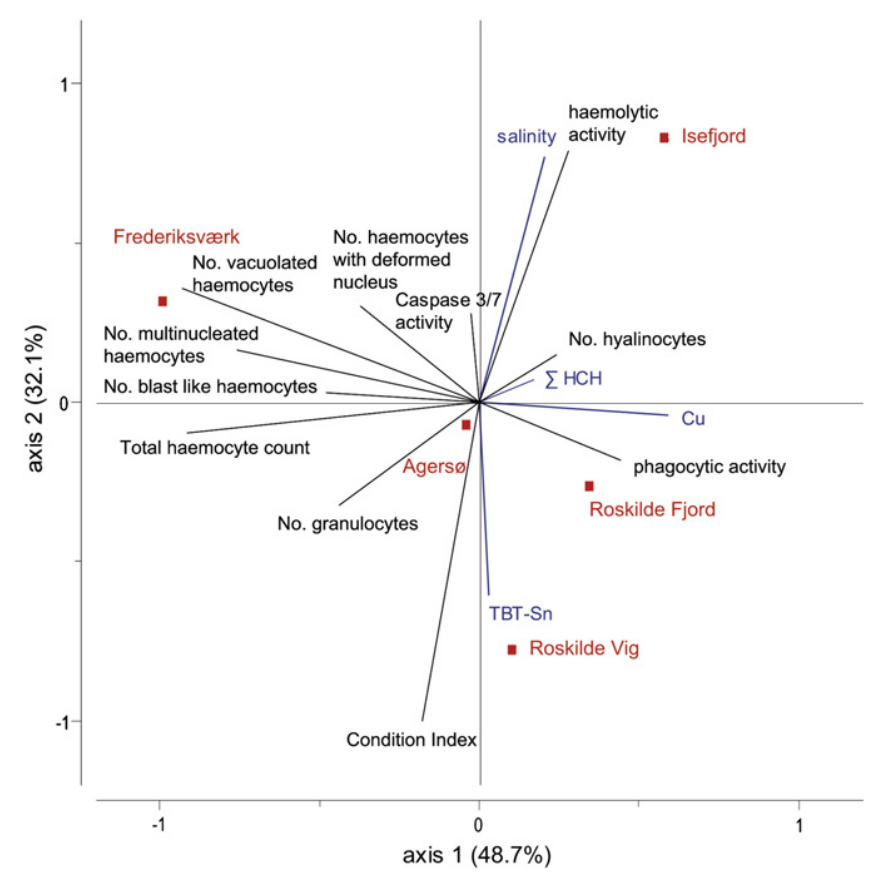

Fig. 8. Redundancy analysis correlation triplot. Explanatory variables selection based on collinearity (VIF < 3): salinity, copper, TBT-Sn and $\sum$ HCH. Axis 1 represented $48.7 \%$ and axis $232.1 \%$ of the variance in the data. Angles between lines indicate correlation (the smaller the angle the more the two variables are positively correlated, lines opposite of each other are negatively correlated, perpendicular lines are not correlated). 
the following variables) suggested, that salinity accounted for $25.13 \%(F=3.336 ; P<0.01)$, TBT of $19.95 \%(F=3.288 ; P<0.01)$, copper in $23.37 \%(F=3.648 ; P<0.01)$ and $\sum \mathrm{HCH}$ for $9.3 \%$ $(F=4.112 ; P<0.001)$ of the observed variances.

\section{Discussion}

As in previous studies or results suggest that the immune system is likely to be affected by contaminants, even at levels that are not toxic (Auffret et al., 2006; Duchemin et al., 2008; Liu et al., 2009), eventually compromising disease susceptibility. The health of an organism is dependent on an effective immune response, which - in bivalves - is employed by haemocytes and humoral factors (Galloway and Goven, 2006; Pipe and Coles, 1995).

To date, immunotoxicity studies focussed on mussels from marine waters (30-37\%) (Cajaraville et al., 1996; Hannam et al., 2009; Pipe et al., 1999) or acute salinity stress (Bussell et al., 2008; Malagoli et al., 2007; Matozzo et al., 2007; Reid et al., 2003). However, immune responses in mussels from brackish seas and waters with naturally occurring and consistent salinity gradients are likely to be affected by low salinities additional to contaminants. Thus, we studied the confounding impact of salinity differences on a set of different cellular and humoral immune functions in the blue mussel to test their applicability as biomarkers for immunotoxic effects in a brackish environment. Our results showed that cellular and morphological endpoints were more influenced by contaminants, whereas humoral (cell-free) immune responses were primarily governed by salinity.

A common response towards contamination is the change in the number of circulating haemocytes, which has been shown to be affected by bacterial infection (Ciacci et al., 2009; Parisi et al., 2008), aquaculture (Fotedar et al., 2006) and copper exposure (Pipe et al., 1999). Contrary to results from studies on the effect of rigorous salinity reductions on immune responses (Bussell et al., 2008; Matozzo et al., 2007; Reid et al., 2003), the consistent salinity gradient in the Danish waters did not cause reductions of the number in circulating haemocytes. However, the station with the highest determined PCB body burden, Frederiksværk (15\%), was characterized by high numbers of circulating haemocytes (THC) accompanied by numerous occurrences of morphological abnormalities as well as lowered phagocytic activity.

Previous studies showed that histological changes in mussel tissues are sound markers of health status (Bignell et al., 2008; Sunila, 1987). However, altered haemocyte morphology has not been reported yet. Here, we showed that haematological staining can be employed for the assessment of morphological changes in haemocytes. Particularly noticeable was the occurrence of vacuolation in haemocytes at Frederiksværk. Vacuolation has been described as a potential marker for environmental stress in mussel tissues, such as the epithelial (Auffret, 1988) and digestive cells (Thompson et al., 1978), though descriptions of vacuolation events in haemocytes are lacking. Henics and Wheatley (1999) provided a review about the occurrence and implications of cytoplasmic vacuolation in cultured mammalian cells, suggesting that this abnormality primarily reflects an adaptative, survival response to a wide range of environmental factors, which is reversible but could lead to a particular and distinctive form of cell death (rather than apoptosis). Additionally, McCormick-Ray and Howard (1991) excluded haemocytes with vacuoles in a morphology and mobility study as those may have been dead or dying cells. The correlation of high values of THC with occurrences of morphological changes, particularly vacuolation, may suggest a compensation of reduced cell viability. In agreement with Henics and Wheatley (1999), we therefore suggest that vacuolation in mussel haemocytes may be implemented as a marker for decreased cell viability.
Even though caspase 3/7 activity, a measure for apoptosis, was not significantly altered, a tendency of their occurrence in combination with morphological abnormalities can be seen in the RDA correlation triplot. Hence, programmed cell death may have been employed as another form to discard damaged haemocytes to prevent inflammation of surrounding tissues. In addition, cell death may have been induced via a caspase-independent pathway (i.e. via apoptosis-inducing factor, AIF; Sokolova, 2009), which would not be detected through caspase activity measurements. Further, Goedken et al. (2005) found that caspase activity was suppressed in oysters (Crassostrea virginica) from low saline waters in comparison to oysters maintained in a higher saline environment, probably due to increased flushing by freshwater from rivers resulting in less parasite infections and less damaged haemocytes. However this explanation is focused on infection rates only, which underpins the need of a combined approach, including environmental factors, pollutants and infectious parasites. Furthermore, a slight increase of blast-like haemocytes, which have been described and are discussed as precursors of granulocytes and hyalinocytes (Hine, 1999; Moore and Lowe, 1977; Travers et al., 2008), did correlate with elevated THCs. Hence, the increase of circulating haemocytes may be due to a stimulated migration of cells from the tissues as well as an increased production of haemocytes, as proposed by Pipe et al. (1999). The latter would explain the low apoptosis rate, albeit the function of those haemocytes as well as their genesis remains unclear to date. Contrary to findings by Bussell et al. (2008) and Reid et al. (2003), the composition of the haemocyte types regarding granulocytes and hyalinocytes were not significantly altered by low salinities.

The effective uptake and destruction of pathogens is an essential immune response, hence its functioning is substantial for maintaining the health of to organism. The assessment of phagocytosis or rather the ability of haemocytes to phagocytose has been the centre of numerous studies evaluating immunotoxicity of contaminants (Canesi et al., 2007; Duchemin et al., 2008; Hannam et al., 2009; Pipe et al., 1999) as well as in experiments assessing salinity effects on the immune system (Bussell et al., 2008; Malagoli et al., 2007; Matozzo et al., 2007; Reid et al., 2003). The latter were emphasised on drastic salinity changes (i.e. due to heavy rain fall) rather than on regions with salinity gradients. In laboratory studies conducted by Matozzo et al. (2007) and Bussell et al. (2008), a reduction of salinity from $34 \%$ to $28 \%$ (for 7 days; Mytilus edulis) and from $32 \%$ to $16 \%$ (for 2 days, Chamelea gallina), respectively, resulted in decreased phagocytic activity, whereas our results suggest that phagocytic activity of molluscan haemocytes adapted to low salinities is not governed by the surrounding environment. As mentioned above lowered phagocytic activity was determined in mussels with the highest PCB body burden. Canesi et al. (2003) found that certain PCB congeners indeed have an impact on immune responses and cell signalling pathways, affecting lysozyme release and microbicidal activity, as well as gene expression. Further, increased phagocytic activity levels correlated with elevated copper concentrations in mussel tissues, particularly from Roskilde Fjord. Similar results have been found by Pipe et al. (1999), who showed that low concentrations (up to $0.05 \mathrm{ppm}$ ) of copper stimulated, whereas higher concentrations $(0.5 \mathrm{ppm})$ suppressed immune responses such as total haemocyte count, extracellular superoxide production and phagocytic activity. Such a stimulation of the immune system without causative pathogens may by energetically costly and have unfavourable effects in long term exposure, particularly since copper concentrations have been increasing in the regions in question (personal communication, Jakob Strand), possibly due to extensive implementation of copper in antifouling paint.

Humoral factors, as assessed by the lysis of erythrocytes by cellfree haemolymph, were positively correlated with salinity. Malagoli 
et al. (2008) showed that haemolytic activity is subject to fluctuations during the year with high values during the summer. Since environmental conditions (temperature, salinity) are likely to influence those modifications of the humoral immune response, we do not recommend the application as biomarker in a region with a salinity gradient such as the Baltic Sea. However, Hannam et al. (2009) assessed haemolytic activity based on haemolymph containing haemocytes. Even though this technique does not give an insight on mere humoral effects, it does provide a measure on the capability of haemocytes to lyse pathogens extracellularly.

Contrary to the presumption that mussels at lower salinities would show lower condition indices based on increased catabolism (Prevodnik et al., 2007; Tedegren and Kautsky, 1986), individuals collected at higher salinities had significantly lower condition indices than those from stations with lower salinities. It has been suggested that this aspect may be explained by the incapability of bivalves to maintain a necessary metabolic rate during starvation (Reid et al., 2003), reflecting seasonal effects in the present study. In terms of seasonal effects on the immune functioning of Baltic mussels data is lacking as this point. This study was conducted in November (sea surface temperatures from 8 to $10{ }^{\circ} \mathrm{C}$ ), however temperatures in 2009 ranged from $0{ }^{\circ} \mathrm{C}$ in winter to $21{ }^{\circ} \mathrm{C}$ in summer (BSH, 2011).

Overall, the multivariate analysis of the present data via variation partitioning (redundancy analysis) showed evidence that the majority of the observed variance in the biological responses can be accounted for contaminants. Thus, the observed biological endpoints, particularly phagocytic activity and morphological abnormalities of haemocytes, may provide sensitive measures in biomonitoring programmes in the Baltic Sea within the range of the studied salinity gradient. Further, the results indicated that the assessment of biological parameters at various levels of biological organization in combination with chemical analyses is essential to obtain a broad picture of effects caused by environmental factors and contaminants. In conclusion, we suggest the evaluation of phagocytic activity as well as morphological alterations of molluscan haemocytes as biomarkers in the studied salinity range $(11-19 \%$ ). Salinities decline to $3 \%$ in the Baltic Sea, hence the application and applicability of those biomarkers must be subject of further studies.

\section{Acknowledgements}

Participants of this study have received funding from the European Community's Seventh Framework Programme (FP/20072013) under grant agreement $n^{\circ} 217246$ made with the joint Baltic Sea research and development programme BONUS. Further, the contaminant data was provided from cooperation with the marine part of the Nationwide Monitoring and Assessment Programme for the Aquatic and Terrestrial Environment (NOVANA) in Denmark. Maps were obtained by HELCOM ${ }^{\circledR}$ and kindly arranged by Christian Schütz (konzeptklar ${ }^{\circledR}$ ). We would like to thank Sabine Schäfer for assissting $\mathrm{N}$. Höher in the lab during this sampling campaign.

\section{References}

Aladaileh, S., Nair, S.V., Birch, D., Raftos, D.A., 2007. Sydney rock oyster (Saccostrea glomerata) hemocytes: morphology and function. Journal of Invertebrate Pathology 96, 48-63.

Auffret, M., 1988. Histopathological changes related to chemical contamination in Mytilus edulis from field and experimental conditions. Marine Ecology Progress Series 46, 101-107.

Auffret, M., Rousseau, S., Boutet, I., Tanguy, A., Baron, J., Moraga, D., Duchemin, M., 2006. A multiparametric approach for monitoring immunotoxic responses in mussels from contaminated sites in Western Mediterranea. Ecotoxicology and Environmental Safety 63, 393-405.
Bignell, J., Dodge, M., Feist, S., Lyons, B., Martin, P., Taylor, N., Stone, D., Travalent, L., Stentiford, G., 2008. Mussel histopathology: effects of season, disease and species. Aquatic Biology 2, 1-15.

Borcard, D., Legendre, P., Drapeau, P., 1992. Partialling out the Spatial component of ecological variation. Ecology 73, 1045-1055.

Broeg, K., Lehtonen, K.K., 2006. Indices for the assessment of environmental pollution of the Baltic Sea coasts: integrated assessment of a multi-biomarker approach. Marine Pollution Bulletin 53, 508-522.

BSH, 2011. Sea Surface Temperatures (Monthly Means and Anomalies).

Bussell, J.A., Gidman, E.A., Causton, D.R., Gwynn-Jones, D., Malham, S.K., Jones, M.L.M., Reynolds, B., Seed, R., 2008. Changes in the immune response and metabolic fingerprint of the mussel, Mytilus edulis (Linnaeus) in response to lowered salinity and physical stress. Journal of Experimental Marine Biology and Ecology 358, 78-85.

Cajaraville, M.P., Olabarrieta, I., Marigomez, I., 1996. In vitro activities in mussel hemocytes as biomarkers of environmental quality: a case study in the Abra estuary (Biscay Bay). Ecotoxicology and Environmental Safety 35, 253-260.

Canesi, L., Betti, M., Ciacci, C., Lorusso, L.C., Pruzzo, C., Gallo, G., 2006. Cell signalling in the immune response of mussel hemocytes. Invertebrate Survival Journal 3, 40-49.

Canesi, L., Ciacci, C., Betti, M., Scarpato, A., Citterio, B., Pruzzo, C., Gallo, G., 2003. Effects of PCB congeners on the immune function of Mytilus hemocytes: alterations of tyrosine kinase-mediated cell signaling. Aquatic Toxicology 63, 293-306.

Canesi, L., Gallo, G., Gavioli, M., Pruzzo, C., 2002. Bacteria-hemocyte interactions and phagocytosis in marine bivalves. Microscopy Research and Technique 57, 469-476.

Canesi, L., Lorusso, L.C., Ciacci, C., Betti, M., Rocchi, M., Pojana, G., Marcomini, A., 2007. Immunomodulation of Mytilus hemocytes by individual estrogenic chemicals and environmentally relevant mixtures of estrogens: in vitro and in vivo studies. Aquatic Toxicology 81, 36-44.

Ciacci, C., Citterio, B., Betti, M., Canonico, B., Roch, P., Canesi, L., 2009. Functional differential immune responses of Mytilus galloprovincialis to bacterial challenge. Comparative Biochemistry and Physiology Part B: Biochemistry and Molecular Biology 153, 365-371.

Conley, D., Kaas, H., Møhlenberg, F., Rasmussen, B., Windolf, J., 2000. Characteristics of Danish estuaries. Estuaries and Coasts 23, 820-837.

Dagnino, A., Allen, J.I., Moore, M.N., Broeg, K., Canesi, L., Viarengo, A., 2007. Development of an expert system for the integration of biomarker responses in mussels into an animal health index. Biomarkers 12, 155-172.

Dahllöf, I., Andersen, J.H., 2009. Hazardous and Radioactive Substances in Danish Marine Waters. Status and Temporal Trends. National Environmental Research Institute, Aarhus University, Denmark.

Davenport, J., Chen, X., 1987. A comparison of methods for the assessment of condition in the mussel (Mytilus edulis L.). Journal of Molluscan Studies 53, 293-297.

Duchemin, M.B., Auffret, M., Wessel, N., Fortier, M., Morin, Y., Pellerin, J., Fournier, M., 2008. Multiple experimental approaches of immunotoxic effects of mercury chloride in the blue mussel, Mytilus edulis, through in vivo, in tubo and in vitro exposures. Environmental Pollution 153, 416-423.

Dyrynda, E.A., Pipe, R.K., Burt, G.R., Ratcliffe, N.A., 1998. Modulations in the immune defences of mussels (Mytilus edulis) from contaminated sites in the UK. Aquatic Toxicology 42, 169-185.

Fenech, M., Chang, W.P., Kirsch-Volders, M., Holland, N., Bonassi, S., Zeiger, E., 2003. HUMN project: detailed description of the scoring criteria for the cytokinesisblock micronucleus assay using isolated human lymphocyte cultures. Mutation Research/Genetic Toxicology and Environmental Mutagenesis 534, 65-75.

Fotedar, S., Evans, L., Jones, B., 2006. Effect of holding duration on the immune system of western rock lobster, Panulirus cygnus. Comparative Biochemistry and Physiology Part A: Molecular \& Integrative Physiology 143, 479-487.

Galloway, T.S., Depledge, M.H., 2001. Immunotoxicity in Invertebrates: measurement and Ecotoxicological Relevance. Ecotoxicology 10, 5-23.

Galloway, T.S., Goven, A., 2006. Invertebrate immunotoxicology. In: Luebke, R. (Ed.), Immunotoxicology and Immunopharmacology. CRC Press, Boca Raton, pp. 365-383.

Goedken, M., Morsey, B., Sunila, I., Dungan, C., De Guise, S., 2005. The effect of temperature and salinity on apoptosis of Crassostrea virginica hemocytes and Perkinsus marinus. Journal of Shellfish Research 24, 177-183.

Hannam, M.L., Bamber, S.D., Sundt, R.C., Galloway, T.S., 2009. Immune modulation in the blue mussel Mytilus edulis exposed to North Sea produced water. Environmental Pollution 157, 1939-1944.

Henics, T., Wheatley, D.N., 1999. Cytoplasmic vacuolation, adaptation and cell death: a view on new perspectives and features. Biology of the Cell 91, 485-498.

Hine, P.M., 1999. The inter-relationships of bivalve haemocytes. Fish \& Shellfish Immunology 9, 367-385.

Kautsky, N., 1982. Quantitative studies on gonad cycle, fecundity, reproductive output and recruitment in a Baltic Mytilus edulis population. Marine Biology 68, $143-160$.

Kiss, T., 2010. Apoptosis and its functional significance in molluscs. Apoptosis 15, 313-321.

Krysko, D.V., Vanden Berghe, T., D’Herde, K., Vandenabeele, P., 2008. Apoptosis and necrosis: detection, discrimination and phagocytosis. Methods 44, 205-221.

Larsen, M.M., Dahllöf, I., Pedersen, B., 2011a. Miljøfarlige Stoffer I Muslinger, Teknisk Anvisning for Marin Overvågning (NOVANA 2011-2015). Danmarks Miljøundersøgelser, Aarhus Universitet, p. 20. 
Larsen, M.M., Strand, J., Christensen, J.H., Vorkamp, K., Hansen, A.B., Andersen, O., 2011b. Metals and organotins in multiple bivalve species in a one-off global survey. Journal of Environmental Monitoring 13, 1793-1802.

Legendre, P., 2008. Studying beta diversity: ecological variation partitioning by multiple regression and canonical analysis. Journal of Plant Ecology 1, 3-8.

Liu, J., Pan, L.-Q., Zhang, L., Miao, J., Wang, J., 2009. Immune responses, ROS generation and the haemocyte damage of scallop Chlamys farreri exposed to Aroclor 1254. Fish \& Shellfish Immunology 26, 422-428.

Malagoli, D., Casarini, L., Fiori, F., Ottaviani, E., 2008. Cytotoxic activity by the mussel Mytilus galloprovincialis and the Venus clam Chamelea gallina in the Adriatic sea in 2007. Invertebrate Survival Journal 5, 50-53.

Malagoli, D., Casarini, L., Sacchi, S., Ottaviani, E., 2007. Stress and immune response in the mussel Mytilus galloprovincialis. Fish \& Shellfish Immunology 23, 171-177.

Matozzo, V., Monari, M., Foschi, J., Serrazanetti, G., Cattani, O., Marin, M., 2007. Effects of salinity on the clam Chamelea gallina. Part I: alterations in immune responses. Marine Biology 151, 1051-1058.

McCormick-Ray, M.G., Howard, T., 1991. Morphology and mobility of oyster hemocytes: Evidence for seasonal variations. Journal of Invertebrate Pathology 58, 219-230.

Moore, M.N., Lowe, D., 2004. Biological effects of contaminants: measurement of Lysosomal membrane stability. In: Keizer, P.D. (Ed.), ICES Techniques in Marine Environmental Sciences, p. 31.

Moore, M.N., Lowe, D.M., 1977. The cytology and cytochemistry of the hemocytes of Mytilus edulis and their responses to experimentally injected carbon particles. Journal of Invertebrate Pathology 29, 18-30.

Oehlmann, J., Schulte-Oehlmann, U., 2003. Molluscs as bioindicators. In: Markert, B.A., Breure, A.M., Zechmeister, H.G. (Eds.), Trace Metals and Other Contaminants in the Environment. Elsevier, pp. 577-635.

OSPAR, 1999. JAMP Guidelines for Monitoring Contaminants in Biota, London, p. 120.

Parisi, M.-G., Li, H., Jouvet, L.B.P., Dyrynda, E.A., Parrinello, N., Cammarata, M., Roch, P., 2008. Differential involvement of mussel hemocyte sub-populations in the clearance of bacteria. Fish \& Shellfish Immunology 25, 834-840.

Pipe, R.K., Coles, J.A., 1995. Environmental contaminants influencing immune function in marine bivalve molluscs. Fish \& Shellfish Immunology 5, 581-595.

Pipe, R.K., Coles, J.A., Carissan, F.M.M., Ramanathan, K., 1999. Copper induced immunomodulation in the marine mussel, Mytilus edulis. Aquatic Toxicology $46,43-54$.

Pirger, Z., Rácz, B., Kiss, T., 2009. Dopamine-induced programmed cell death is associated with cytochrome $\mathrm{c}$ release and caspase- 3 activation in snail salivary gland cells. Biology of the Cell 101, 105-116.

Prevodnik, A., Gardeström, J., Lilja, K., Elfwing, T., McDonagh, B., Petrovic, N., Tedengren, M., Sheehan, D., Bollner, T., 2007. Oxidative stress in response to xenobiotics in the blue mussel Mytilus edulis L.: evidence for variation along a natural salinity gradient of the Baltic Sea. Aquatic Toxicology 82, 63-71.
Rank, J., Lehtonen, K.K., Strand, J., Laursen, M., 2007. DNA damage, acetylcholinesterase activity and lysosomal stability in native and transplanted mussels (Mytilus edulis) in areas close to coastal chemical dumping sites in Denmark. Aquatic Toxicology 84, 50-61.

Reid, H.I., Soudant, P., Lambert, C., Paillard, C., Birkbeck, T.H., 2003. Salinity effects on immune parameters of Ruditapes philippinarum challenged with Vibrio tapetis. Diseases of Aquatic Organisms 56, 249-258.

Schiedek, D., Broeg, K., Barsiene, J., Lehtonen, K.K., Gercken, J., Pfeifer, S. Vuontisjärvi, H., Vuorinen, P.J., Dedonyte, V., Koehler, A., Balk, L., Schneider, R., 2006. Biomarker responses as indication of contaminant effects in blue mussel (Mytilus edulis) and female eelpout (Zoarces viviparus) from the southwestern Baltic Sea. Marine Pollution Bulletin 53, 387-405.

Seed, R., 1975. Reproduction in Mytilus (Mollusca: Bivalvia) in European waters. Pubblicazioni della Stazione Zoologica di Napoli 39, 317-334.

Seed, R., 1976. Ecology. In: Bayne, B.L. (Ed.), Marine Mussels: Their Ecology and Physiology. Cambridge University Press, Cambridge.

Smedes, F., 1999. Determination of total lipid using non-chlorinated solvents. Analyst $124,1711-1718$.

Sokolova, I.M., 2009. Apoptosis in molluscan immune defense. Invertebrate Survival Journal 6, 49-58.

Strand, J., Jacobsen, J.A., Pedersen, B., Granmo, Å., 2003. Butyltin compounds in sediment and molluscs from the shipping strait between Denmark and Sweden. Environmental Pollution 124, 7-15.

Sunila, I., 1987. Histopathology of mussels (Mytilus edulis L.) from the Tvärminne area, Gulf of Finland (Baltic Sea). Annales Zoologici Fennici 24, 55-69.

Tedegren, M., Kautsky, N., 1986. Comparative study of the physiology and its probably effect on size in blue mussels (Mytilus edulis) from the North Sea and the Northern Baltic Proper. Ophelia 25, 147-155.

Thompson, R.J., Bayne, C.J., Moore, M.N., Carefoot, T.H., 1978. Haemolymph volume, changes in the biochemical composition of the blood, and cytological responses of the digestive cells in Mytilus californianus Conrad, induced by nutritional, thermal and exposure stress. J. Comp. Physiol. B. Biochemical, Systemic, Environ. Physiol. 127, 287-298.

Travers, M.-A., Mirella da Silva, P., Le Goïc, N., Marie, D., Donval, A., Huchette, S. Koken, M., Paillard, C., 2008. Morphologic, cytometric and functional characterisation of abalone (Haliotis tuberculata) haemocytes. Fish \& Shellfish Immunology 24, 400-411.

Vorkamp, K., Strand, J., Christensen, J.H., Svendsen, T.C., Lassen, P., Hansen, A.B. Larsen, M.M., Andersen, O., 2010. Polychlorinated biphenyls, organochlorine pesticides and polycyclic aromatic hydrocarbons in a one-off global survey of bivalves. Journal of Environmental Monitoring 12, 1141-1152.

Widdows, J., Donkin, P., 1992. Mussels and environmental contaminants: bioaccumulation and physiological Aspects. In: Gosling, E. (Ed.), The Mussel Mytilus. Elsevier Press, Amsterdam, pp. 383-424.

Zuur, A., Ieno, E.N., Smith, G.M., 2007. Principal Component Analysis and Redundancy Analysis, Analysing Ecological Data. Springer, New York, pp. 193-224. 